Review

\title{
Current Advances in Biofouling Mitigation in Membranes for Water Treatment: An Overview
}

\author{
Daniela Pichardo-Romero, Zahirid Patricia Garcia-Arce, Alejandra Zavala-Ramírez and \\ Roberto Castro-Muñoz *D
}

Tecnologico de Monterrey, Campus Toluca, Avenida Eduardo Monroy Cárdenas 2000 San Antonio Buenavista, Toluca de Lerdo 50110, Mexico; dany.pichardo99@gmail.com (D.P.-R.); A01363407@itesm.mx (Z.P.G.-A.); A01421769@itesm.mx (A.Z.-R.)

* Correspondence: food.biotechnology88@gmail.com or castromr@tec.mx

Received: 9 January 2020; Accepted: 27 January 2020; Published: 5 February 2020

\begin{abstract}
Membranes, as the primary tool in membrane separation techniques, tend to suffer external deposition of pollutants and microorganisms depending on the nature of the treating solutions. Such issues are well recognized as biofouling and is identified as the major drawback of pressure-driven membrane processes due to the influence of the separation performance of such membrane-based technologies. Herein, the aim of this review paper is to elucidate and discuss new insights on the ongoing development works at facing the biofouling phenomenon in membranes. This paper also provides an overview of the main strategies proposed by "membranologists" to improve the fouling resistance in membranes. Special attention has been paid to the fundamentals on membrane fouling as well as the relevant results in the framework of mitigating the issue. By analyzing the literature data and state-of-the-art, the concluding remarks and future trends in the field are given as well.
\end{abstract}

Keywords: membrane technologies; biofouling; composite membranes; polymer blending

\section{Introduction}

To date, different new ways of water processing have been proposed to optimize the production and yield, considering also the reduction of production costs and time [1,2]. Nowadays, one of these ways has been membrane technology, which was, for the first time, introduced by Bechold in 1907, who used ultrafiltration processes [3]. Since that time, membrane-based technologies began to gain popularity as separation processes. They are among the most significant advances in chemical and biological process engineering. Membrane processes are well defined due to the membrane being a primary tool for separating different types of molecules [4]. In principle, membranes can be classified into two different categories according to the membrane material, organic (based on polymers) and inorganic (e.g., glass, ceramic, silica, graphene, metal oxide, among others) $[5,6]$. Moreover, membrane-based technologies are classified based on their driving force, especially for the pressure-driven membrane processes, where the pore size in the membrane is the key characteristic that distinguishes between Microfiltration (MF) (pore size between 100 and 10,000 nm), Ultrafiltration (UF) (pore size between 2 and $100 \mathrm{~nm}$ ) and Nanofiltration (NF) (pore size 0.5-2 nm)[7]. For instance, Table 1 enlists the main pressure requirements needed for these processes to carry out the separation, and the separation mechanism that may take place. 
Table 1. Classification and main parameters of Microfiltration (MF), Ultrafiltration (UF) and Nanofiltration (NF).

\begin{tabular}{cccc}
\hline Membrane Process & \multicolumn{2}{c}{ Required Pressure (bar) } & \multirow{2}{*}{$\begin{array}{c}\text { Typical Separation } \\
\text { Mechanism }\end{array}$} \\
\cline { 2 - 3 } & Min. & Max. & Sieving \\
\hline Microfiltration & 0.1 & 2 & Sieving \\
Ultrafiltration & 0.1 & 7 & Sieving and charge effect \\
Nanofiltration & 3 & 25 & S
\end{tabular}

The membrane, as the only separation barrier, is always in contact with the treating solutions, and consequently, they are prone to present chemical or biological deposition of matter [8,9]. Such deposition is the so-called fouling phenomenon. Biofouling implies the adhesion of micro- or macroorganisms as membrane foulant, and it represents the "vulnerable" part of the membrane process since microorganisms can proliferate over time. It has been established that biofouling contributes to over $45 \%$ of membrane fouling [10]. Microfouling originated by unicellular or pluricellular microorganisms, such as bacteria, yeast, or fungi, that may form a complex biofilm by mono-species or multi-species, while macrofouling was associated with bigger or visible organisms [11].

Typically, there are four types of fouling mechanisms, which were established by Hermia [12], that can take place in membrane processes: complete pore blocking, partial pore blocking, internal pore blocking, and cake formation. In order to inhibit or, at least control such mechanisms, the chemical nature of the foulants (e.g., organic, inorganic, or biological) must be known due to more than one type of fouling taking place simultaneously in a process, and beyond the classification, the pollutant's nature can provide an overview on the type of fouling and its impact on membrane properties [13]. For instance, the mechanisms can involve adsorption, accumulation, or precipitation either on the surface or inside the membrane's pores. This can have an influence on the separation performance of the membrane, e.g., decrease permeate flux and membrane selectivity, and membrane lifetime [14,15]. Based on such negative effects of biofouling on membranes, several authors have hardly worked on developing new strategies in preparing new concepts of membranes, which may offer enhanced fouling resistance. Therefore, the goal of this review paper is to give an outlook of the ongoing development works at mitigating the biofouling in pressure-driven membrane processes. To better understand the biofouling in membranes, a brief background of such a phenomenon is given, providing the main factors that play a key role in biofouling. Special emphasis has been paid to relevant results in the framework of reducing the issue. By reviewing the literature data and current state-of-the-art, the concluding remarks and future trends in the field are also given.

\section{The Main Factors Playing an Important Role in the Biofouling Phenomenon}

As mentioned previously, four mechanisms have been used to denote the fouling in pressure-driven membrane processes, such as (a) complete pore blocking, (b) partial pore blocking, (c) internal pore blocking, and (d) cake formation [12]. Figure 1 depicts a representation of such fouling mechanisms. In theory, these models follow three fundamentals: (i) constant pressure filtration, (ii) membrane pores are parallel to each other, cylindrical and equal in diameter, and (iii) foulant particles are spherical and non-deformable [12]. Complete pore blocking considers that the fouling occurs on the membrane surface area, and the particles "close" the pores, but no particle is placed on the top of another one [16]. In the case of partial pore blocking, it is also a surface phenomenon, but in this case, particles can be particularly placed on the top of the other [12]. For the internal pore blocking, the foulant particles are deposited inside the pores attaching themselves into the pore walls, and consequently, they change the pore diameter [12,16]. Finally, the cake formation is due to the complete coverage of the membrane surface, where the foulants can compose layers leading to the increment of hydraulic resistance in proportion to the cake layer thickness [12]. 
a)

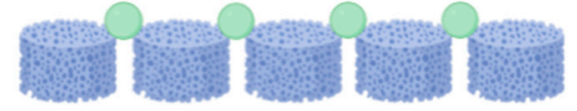

b)

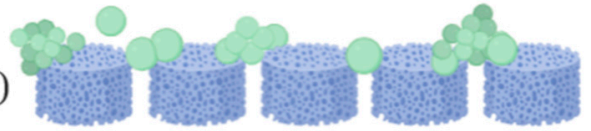

c)

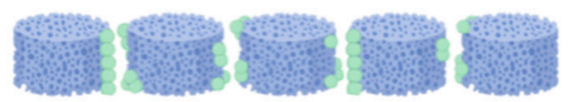

d)

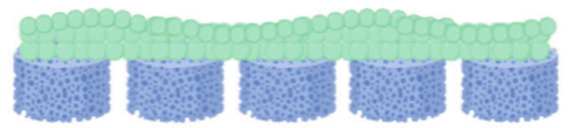

Figure 1. Graphical representation of the fouling mechanisms: (a) complete pore blocking, (b) partial pore blocking, (c) internal pore blocking and (d) cake formation [12].

When dealing with biofouling, the most important elements are microorganisms. Herein, the first step is the adhesion of the microbial cells to the membrane surface inducing the formation of a biofilm layer. The population of microorganisms, that may form the biofilm, are different types of bacteria, protozoa, fungi, and algae [10]. The adhesion to the membrane surface can be promoted by the membrane material since it can act as a substrate (e.g., cellulose acetate membranes). However, some other intrinsic properties of the membrane material and membrane itself, such as hydrophobicity, roughness of the membrane and membrane surface charges, are also crucial for biofilm formation. It is important to mention that such physico-chemical characteristics may change due to the extracellular polymeric substances (EPS) that are secreted by the microorganisms. In particular, this phenomenon contributes to a decrease in the permeation rates [10]. The steps of biofilm formation are depicted in Figure 2 [11]. Initially, proteins are fundamentally important factors in developing biofouling due to the fact that a protein layer provides an optimum environment for microbial colonization. As it is well-known, proteins are composed by amino acids, which possess several functional groups, such as carboxyl, amino and methyl groups. Such functional groups provide a specific hydrophilic or hydrophobic nature to the proteins, and thus, the retention of microorganisms on the membrane occurs through diverse intramolecular forces, such as van der Waals forces, hydrophobic interactions, hydrogen bonding, among others [11].

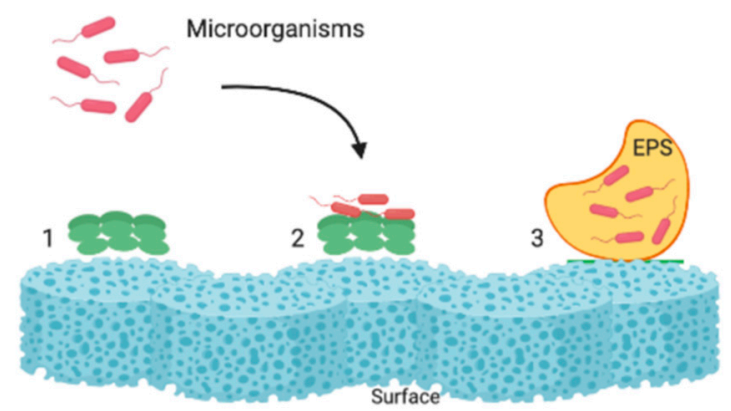

Figure 2. Steps of the biofilm formation: (1) Conditioning film (protein layer). (2) Transport to the surface and immobilization. (3) Attachment to the substrate [11].

Furthermore, different types of fouling may occur during a filtration process depending on multiple factors, including the physico-chemical composition of the feed solution (including $\mathrm{pH}$, nature, etc.), operating parameters (such as feed flow rate, transmembrane pressure, temperature, among others) and the properties of the membrane (such as membrane material, membrane cut-off, charge). 
The simultaneous appearance of the different fouling mechanisms can also take place. For instance, during the ultrafiltration of palm oil mill effluent (POME), Said et al. [17] stated that internal pore blocking, cake formation, and partial pore blocking were taking place, and importantly, they were dependent on the operating conditions. Therefore, this section addresses the main factors which play an important role in fouling formation.

\subsection{Physico-Chemical Composition of the Feed Solution}

According to various studies, the physico-chemical composition of the feed bilk is identified as the most critical issue on membrane biofouling [18]. As the primary element of any composition of feed solutions, the foulants can be categorized into four categories: organic, inorganic, colloidal, and biological, which can also be found among the composition of the feed depending on its origin [19]. These foulants can raise the following severe issues: (i) decrease in membrane flux and thus decrease of permeate production, (ii) degradation of the membrane due to the biofilm forming on its surface, and (iii) increase in pressure differences [20].

Among the different types of foulants, it is likely that the organic ones are the major constituents of wastewater streams. Usually, the organic matter contained in effluents provokes fouling coming from three primary sources: (i) synthetic organic compounds discharged by consumers, or disinfection by-products derived from disinfection processes, (ii) natural organic matter (NOM) generally presented in drinking water, and (iii) soluble microbial products generated during wastewater treatment [19]. In general, some of the main organic compounds found in wastewater are listed in Table 2.

Table 2. Size ranges of typical organic components in biological treated wastewater.

\begin{tabular}{cccc}
\hline Classification & Compound & MW $(\mathbf{D a})$ & Size $(\mu \mathrm{m})$ \\
\hline & Nutrients & $10-10^{2}$ & $<10^{-4}$ \\
& Amino acids & $>10-10^{2.5}$ & $<10^{-4}-10^{-4}$ \\
& Recalcitrant Matter & $>10-10^{3}$ & $<10^{-4}-10^{-3.8}$ \\
& Carbohydrate & $10^{2}-10^{3}$ & $<10^{4}-10^{-3.6}$ \\
& Fatty acid & $10^{3}-10^{3.5}$ & $10^{-4}-10^{-3.3}$ \\
& Chlorophyl & $10^{3}-10^{4}$ & $10^{-3.8}-10^{-3.3}$ \\
Dissolved Organic Matter & Vitamin & $10^{3.3}-10^{6.5}$ & $10^{-3.5}-10^{-1.8}$ \\
(DOM) & Humic acid & $10^{3.6}-10^{7.5}$ & $10^{-3.5}-10^{-1.2}$ \\
& Proteins & $10^{4}-10^{6.5}$ & $10^{-3.1}-10^{-2.4}$ \\
& RNA & $10^{4}-10^{5}$ & $10^{-4.8}-10^{-3.5}$ \\
& Extracellular enzyme & $10^{4}-10^{7}$ & $10^{-3}-<10^{-1}$ \\
& Polysaccharide & $10^{6}-10^{9}$ & $10^{-2}-<10$ \\
& Virus & $>10^{7}-<10^{9}$ & $>10^{-2}-<10$ \\
& Cell fragment & $>10^{7}-10^{9}$ & $10^{-1}-<10$ \\
\hline \multirow{2}{*}{ Particular/Colloidal Organic } & DNA & $>10^{8}$ & $>10^{-1}-10^{3}$ \\
Matter (POM/COM) & Organic debris & $>10^{9}$ & $<10_{-}<10^{2}$ \\
& Bacteria & $>10^{9}$ & $10-10^{3}$ \\
\hline
\end{tabular}

As it can be seen most organic compounds can be classified into two major groups: dissolved organic matter (DOM) and particular/colloidal organic matter (POM) [19]. Particularly, some papers establish that DOM comprises a mixture of several ill-defined aliphatic and phenolic compounds [20], which possess a molecular weight in the range 5000 to 50,000 Da. Such compounds tend to generate an undesirable yellow-black colored water [21].

DOM are typically humic-based molecules and substances which constitute around $90 \%$ of the total of foulants in the feed. These substances represent meaningful and variable proportions of organic matter contained in soils and fresh seawaters, and they are known for affecting the aesthetic quality of water by changing the color and acting as a complexing agent for inorganic compounds. The fact that various authors have supported that humic substances are the most common reaction precursors 
to trihalomethane (chloroform) formation is extremely worrying and has brought many scientists to investigate ways to eliminate these and other foulants from the feed solutions and water [20].

To date, relevant research has been done regarding different pretreatments to prevent biofouling, including coagulation/flocculation (in-line coagulation, pre-coagulation/sedimentation and pre-flocculation), oxidation, ion exchange, adsorption, prefiltration, biofiltration, as well as their possible coupling [19].

\subsection{Effect of Transmembrane Pressure}

As a pressure-driven membrane process, a membrane filtration system should be operated at specific transmembrane pressures, which may provide higher productivity in terms of permeate flux and rejection capacity [22]. However, transmembrane pressure has an important influence on membrane fouling. For instance, when the pressure increases, the permeate flux follows a linear tendency, in other words, the permeate flux is pressure-dependent but there is a critical point where this can no longer happen, and this is well-known as limiting transmembrane pressure. In order to provide a good performance, it is recommended that the membrane systems operate below such critical points in which the fouling is promoted [23]. In the work presented by Jepsen et al. [22], the constant flux operation was shown less fouling with a fixed permeate flux during a desalination process; while less fouling appeared to occur at a constant transmembrane pressure for surface water treatment.

When the pressure is above the critical zone, the flux declines as the pressure increases due to the deposition of particles on the membrane surface; furthermore, the pressure raises the concentration polarization and the collision of particles promoting their attachment to the membrane pores, and consequently, a cake formation occurs [17]. During POME ultrafiltration, authors have compared the type of fouling that can occur varying the transmembrane pressure from 2 to 5 bar. Specifically, at 2 to 4 bar, the fouling was identified as partial or internal pore blocking, while at a pressure of 5 bar, the fouling occurred was related to cake formation [17].

As described above, increasing the driving force results in the growth of a solute layer, and this is well known as the mass transfer-controlled region; this detains the increase of the permeation rate of the components [24]. According to He et al. [24], the operation at high pressure does not necessarily guarantee high permeate flux. This statement was proven in their study on the separation of reactive dye solution, finding the optimum operating pressure for UF membrane below $1.5 \mathrm{MPa}$.

\subsection{Effect of $p H$}

The membranes could be positively or negatively charged depending on the type and nature of feed solution. At this point, the $\mathrm{pH}$ remarkably produces changes on the charges of the membrane due to the disassociation of functional groups [24]. Therefore, depending on the $\mathrm{pH}$ used, the solution can possess charges that are similar or different compared to the membrane, which may cause the repulsion or affinity of the particles towards the membrane. The functional groups that generate negatively charged membranes are carboxylic and sulfonic acid groups, while positively charged membranes can originate from amino groups that accept hydrogen ions in solutions of acidic $\mathrm{pH}$ [25].

It has been observed that $\mathrm{pH}$ has negligible effects on the rejection of dye and salt [24], however, when there is an attractive force between the membrane and the particles, an internal pore-blocking occurs if the size of the particles are smaller than the pore size, then, they can generally go through the pores and then attach to the wall [17]. During the filtration of the calcium sulfate solution, the rejection of calcium sulfate was affected by the $\mathrm{pH}$ of the feed solution, leading to the comparison between a high $\mathrm{pH}$ of the feed solution and a lower $\mathrm{pH}$. Here, an increase in $\mathrm{pH}$ showed higher retention; and a lower $\mathrm{pH}$ caused a lower repulsive force at the membrane surface when the dissociation of functional groups was withheld [25].

Importantly, the $\mathrm{pH}$ increase in the feed impacts the physico-chemical characteristics of the water, as well as the membrane characteristics. In addition to this, the $\mathrm{pH}$ certainly influences the charge or solubility of some components in the feed solution; however, these changes could be used to improve 
rejection expressed as recovery increase and reduce fouling. It is known that at a high $\mathrm{pH}$, organic compounds are more soluble, specifically at a $\mathrm{pH}$ above 10, where the filtration systems that operate at this value or near will help to decrease organic fouling. [26]. On the other hand, higher ionic strength and acidic $\mathrm{pH}$ promote bacterial adhesion by modifying the membrane surface in terms of pore size or shape [27].

\subsection{Effect of the Feed Flow Rate}

The influence of the feed flow velocity on the fouling rate is fundamental to guaranteeing that the system operates at the optimal conditions [28]. In particular, feed flow and hydrodynamic conditions promote the adhesion of particles to the membrane in most of the desalination processes used at an industrial level [27].

When dealing with the filtration of organic matter, the water permeation through the membrane causes the fast formation of a fouling layer, Based on Choi's analysis [29], this comes from the compulsive transport of foulants into the membrane surface by the drag force of permeate flow, which leads to the sealing of pores provoking the fouling layer. Likewise, the moist and low shear environment facilitate the proliferation of bacteria and biofilm formation on the membrane's surface [27].

Another key factor is the concentration polarization since the concentration of microorganisms and nutrients available in the layer directly affects the adhesion and formation of biofilm. Basically, when these elements increase their concentration, the rate of biofouling will increase as well [27]. When the carbon concentration increases in the bulk solution, this can contribute to obtaining higher rates of biofouling, which increases the mass of organic matter (such as microorganisms) present in the biomass [27]. At this point, the element related to the attachment of microorganisms, as well as other organic compounds in the concentration polarization layer, is the lack of convective flow near the membrane surface [27]. Additionally, it is known that both lower crossflow rates and high-water flux increase the rate of pollute accumulation in the boundary layer [27].

Finally, aimed at the reduction of the concentration polarization, it is relevant to understand its dependence on the Reynolds numbers. According to Rezaei et al. [30], the concentration polarization decreases considerably as the Reynolds number increases. This is because high shear stress enhances the mixing phenomenon, allowing to decrease the thickness of the concentration boundary layer and therefore improving the membrane's performance.

\subsection{Effect of Feed Temperature}

Typically, an increase in temperature results in a higher permeate flux, which does not imply the controlled region of the transmembrane pressure. This could be under the critical point or above the critical point. Generally, high temperatures decrease the viscosity of the feed solution, which reduces the resistance to flow and provokes turbulence. Moreover, the increase in temperature also raises the diffusivity and therefore the rate of transport of solutes carried away from the membrane surface and back into the bulk stream [23]. Herein, the phenomenon of temperature reducing feed viscosity also displays a linear increment between the temperature and the permeation flux. The diffusion coefficient increases while the temperature does, causing the mass transfer resistance to decrease [24].

Experimentally, a higher temperature distributes dyes in a uniform way between both phases of the solution and the membrane, which results in a lower rejection. Nonetheless, salt rejection tends to show a different pattern. He et al. [24] attributed such a phenomenon to the minimal temperature effect on charge repulsion and sieving effect. Jin et al. [31] found out that as the temperature increased, the mass transfer was enhanced, and concentration polarization reduced. Additionally, there was a relation between pressure and temperature, e.g., at a higher feed temperature, lower pressure was needed to deliver the desired flux. In Jin's study, the filtration experiments were tested at 15, 25 and $35^{\circ} \mathrm{C}$, and they used a humic acid solution to evaluate the fouling. At those temperatures, the colloids were on average a size of about 200, 80 and $70 \mathrm{~nm}$, respectively; the larger size of humic acid (at $15^{\circ} \mathrm{C}$ ) resulted in a vast cake layer, and as a consequence, the flux decline was bigger [31]. 


\subsection{Effect of the Intrinsic Membrane Properties}

At this point, we have seen that the physical and chemical interactions between foulants and membrane make the understanding of biofouling more complicated. As the fundamental element used for separation, the properties of the membrane are also crucial in understanding the process and thus finding the possibility of mitigating the biofouling phenomenon. Generally, membrane properties can be conceptualized into membrane structure parameters, which include roughness, porosity and pore size, shape and distribution, and membrane/effluent coupling parameters, including membrane material, surface charge, and hydrophobicity/hydrophilicity. [19]. Regarding the roughness, which refers to the topology of the membrane, it is known that it increases the surface area and thus affects macroscopic properties influencing fouling [32].

On the other hand, when dealing with the pores' features, such as shape, size, and distribution, the membrane features must ideally display the right balance aiming to diminish fouling. Usually, membranes with larger pores are more prone to irreversible fouling due to allowing colloids to penetrate more easily [33]. Membranes, which possess low porosity, demonstrate severe fouling, and hence, suitable pore size and narrow distribution are recommended to control the fouling [19].

Concerning the surface charge, membrane surfaces can display hydrophilic or hydrophobic properties depending on the interfacial tension between water and membrane material. In several works, hydrophobic membranes have been regarded as more prone to fouling compared with hydrophilic ones. This happens because the particles that come from the feed water will accumulate on the hydrophobic surface, minimizing the interfacial tension between water and membrane [34]. Another factor that has a meaningful impact on fouling is electrostatic charge due to membranes that are commonly negatively charged or modified to generate repulsive forces against organic fouling [19]. By considering all these main factors together with operating parameters that influence the biofouling phenomenon, researchers have made a lot of effort to develop new proposals and concepts to face the mitigation of such issues in membrane applications towards water treatment. The next section describes the evolution of the beginnings and current advances in such developments works.

\section{Beginnings of the Development Works Aimed at the Mitigation of Biofouling in Membranes}

Figure 3 shows the first application of membrane processes for several applications and its evolution until the 1990s. The usage of membrane technologies was sparked off during the discovery of the osmosis phenomenon by J. Abbe Nollet in 1784, and after the following years the discovery became of great interest [3]. A few years later, they found out that the biggest bottleneck of this technology was biological fouling or "biofouling", which is, in fact, the current issue. At the early stages of the development of this technology, the uses ranged from water desalination to disinfection, decarbonization, membrane bioreactors, among others [35].

In 1949, when the concept of seawater desalination became of great interest, several scientists began to investigate the application of membrane technologies to this process. However, since seawater is full of contaminants, such as sand, mud and, most importantly, biological matter, the fouling became a huge problem for this application [36]. In such a period, several techniques, including chlorination, coagulation, acid addition, multi-media filtration and dichlorination, were involved in the pretreatment process to prevent/eliminate undesired contaminants [37,38]. Particularly, to prevent the growth of microorganisms, sodium chlorite was also added [39].

In a more advanced way of solving biofouling, the modification of membranes based on a thin polyamide (PA) layer was performed. This was aimed at mitigating the interaction between the foulants and the barrier layer. By adding macromolecules (e.g., poly (ethylene glycol)) to the surface, the membrane was synthesized to be more hydrophilic. Regarding the membrane preparation protocol, the phase inversion protocol was used for asymmetric membranes, in which thin-film-composite (TFC) membranes were prepared by interfacial polymerization. [40]. These modification protocols to face biofouling have been studied for different types of water sources, but their implementation and efficiency should be dependent on the type of water source [41]. 


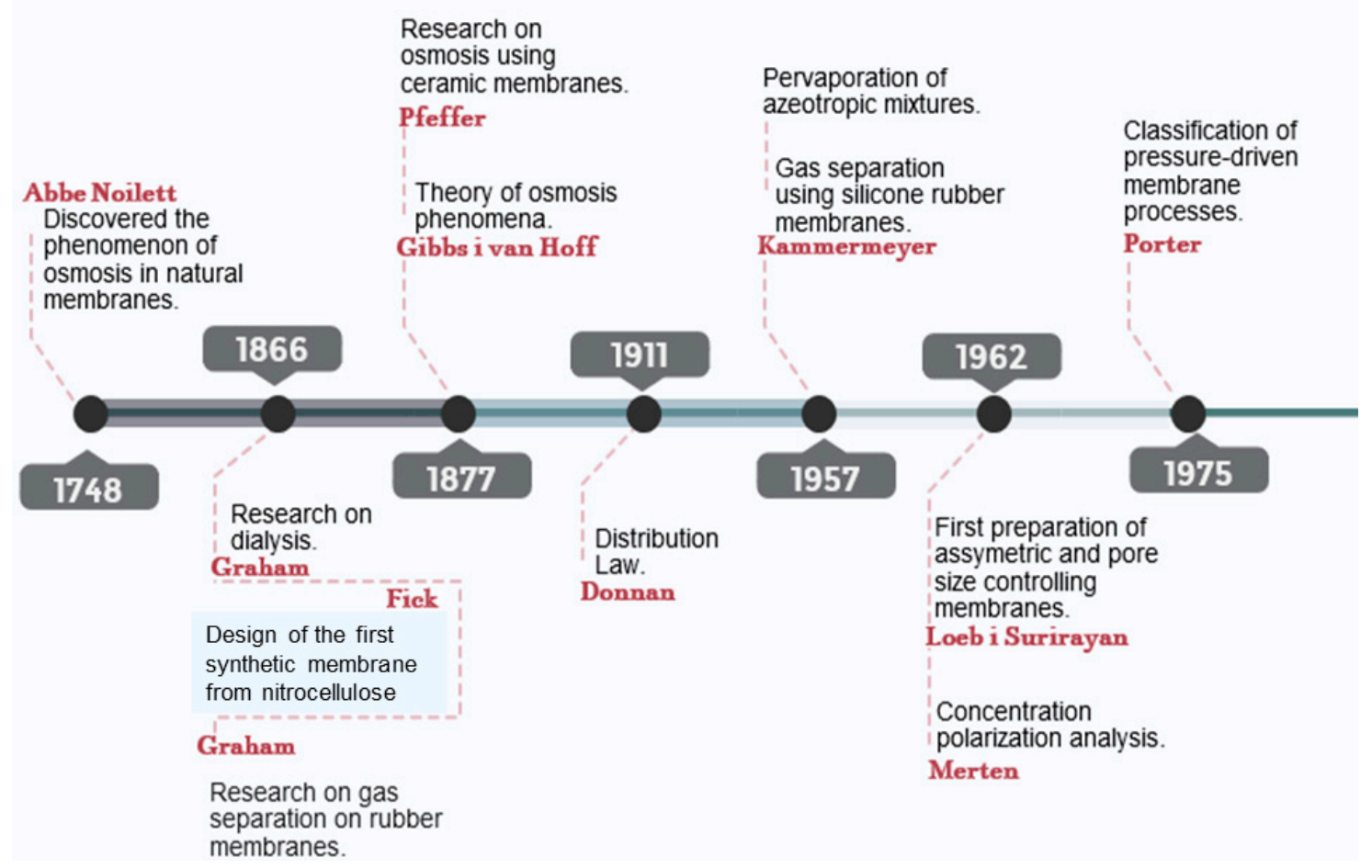

Figure 3. Milestones on the development of membranes from its early beginnings until the 1990s [3].

For a long time, pretreatment with free chlorine was used to prevent and mitigate biofilm and microbial growth but later was avoided since TFC membranes have a low resistance to oxidants. It was then substituted with monochloramine, which resulted in the same oxidizing effect with lower disinfection and it required more frequent cleaning. This was studied by Vikesland and Valentine [41], who suggested the promising use of monochloramine as an oxidant for Fe (II) removal in the production of drinking water.

Efforts have also been made on coating the membranes' surface with antimicrobial products, which could modify its physical-chemical structure to diminish the biofouling effect. Here, an analysis of the biological part that triggers biofouling has been widely studied. For instance, it has been reported that by inhibiting ATP synthesis using chemical uncoupling, the granular sludge biofilm cannot be formed. Besides this, recommendations have been made to study the intercommunication between cells, where the analysis of preventing such signals could avoid biofilm formation [35].

Another way of mitigating biofouling deals with physico-chemical methods, such as sonication, backwashing, and chemical washing, in which acids are the chemicals most commonly used for attempting the removal of multivalent cationic species, metal chelating agents [42], enzymes, and surfactants [35,43]. Membrane bioreactor technology (MBT), which is used in various wastewater treatments, has been used for evaluating the transmembrane pressure (TMP), charge variation, different $\mathrm{pH}$ values and salt concentrations, crossflow, and membrane hydrophilicity. The effect of such parameters has also been studied in order to decrease fouling [44]. As a summary, Table 3 reports the most remarkable studies in which the first attempts were directly focused on membrane fouling. 
Table 3. Remarkable studies regarding membrane fouling from early 2010.

\begin{tabular}{|c|c|c|c|}
\hline Year & Authors & Remark of the Study & Reference \\
\hline 1784 & J. Abbe Nollet & $\begin{array}{l}\text { Discovery of the osmosis phenomenon in natural } \\
\text { membranes }\end{array}$ & {$[4]$} \\
\hline 1999 & Durham and Walton & $\begin{array}{l}\text { Description of the early stages of pretreatment in } \\
\text { desalination processes }\end{array}$ & {$[36]$} \\
\hline 1997 & Amjad & Starting solutions for fouling & [37] \\
\hline 2001 & Isaias & Pretreatment for fouling in desalination processes & [38] \\
\hline 2002 & Vikesland and Valentine & $\begin{array}{l}\text { Studies in monochloramine as an oxidant for Fe } \\
\text { (II) removal in drinking water treatment. }\end{array}$ & [41] \\
\hline 2006 & Le-Clench, Chen and Fane & $\begin{array}{l}\text { Early stages of studies in membrane fouling for } \\
\text { bioreactors used in wastewater treatment }\end{array}$ & {$[44]$} \\
\hline 2008 & Khawaji, Kutubkhanah and Wie & $\begin{array}{l}\text { Basic aspects and advances in seawater } \\
\text { desalination, and fouling. }\end{array}$ & [39] \\
\hline 2008 & $\begin{array}{l}\text { Abu, Tarboush, Rana, Matsuura, } \\
\text { Arafat and Narbaitz. }\end{array}$ & $\begin{array}{l}\text { Research in polyamide membranes via surface } \\
\text { modification for desalination }\end{array}$ & {$[40]$} \\
\hline 2010 & Porcelli and Judd & Cleaning of drinking water using membranes & [42] \\
\hline 2011 & $\mathrm{Xu}$ and Liu & Membrane fouling and cleaning. & [35] \\
\hline
\end{tabular}

\section{Current Advances in Biofouling Mitigation in Membranes}

\subsection{Polymer Blending}

Figure 4 provides an overview of the evolution of the current advances in biofouling mitigation in membranes. To avoid superfluous fouling, modified membranes have been fabricated in which typical modifications include zwitterions, composite nanomaterials and polymer blending [15]. To date, there is unanimity in research for the first definition and stage of fouling, which refers to the adhesion of foulants to the surface. Such adhesion is mainly attributed to van der Waals attractions, hydrogen bonding, and hydrophobic interactions [14]. Therefore, one of the most forthright and effective strategies comprise surface modification and the design of novel membranes by rendering antifouling properties [13]. Firstly, it must be considered that a copolymer is the merging of a matrix polymer and hydrophilic blocks enable the intermolecular interactions accordingly facilitating the blending. These membranes are sometimes weak, identified as one drawback, and if the polymers are not well interconnected, their permeability will not be suitable [45]. 


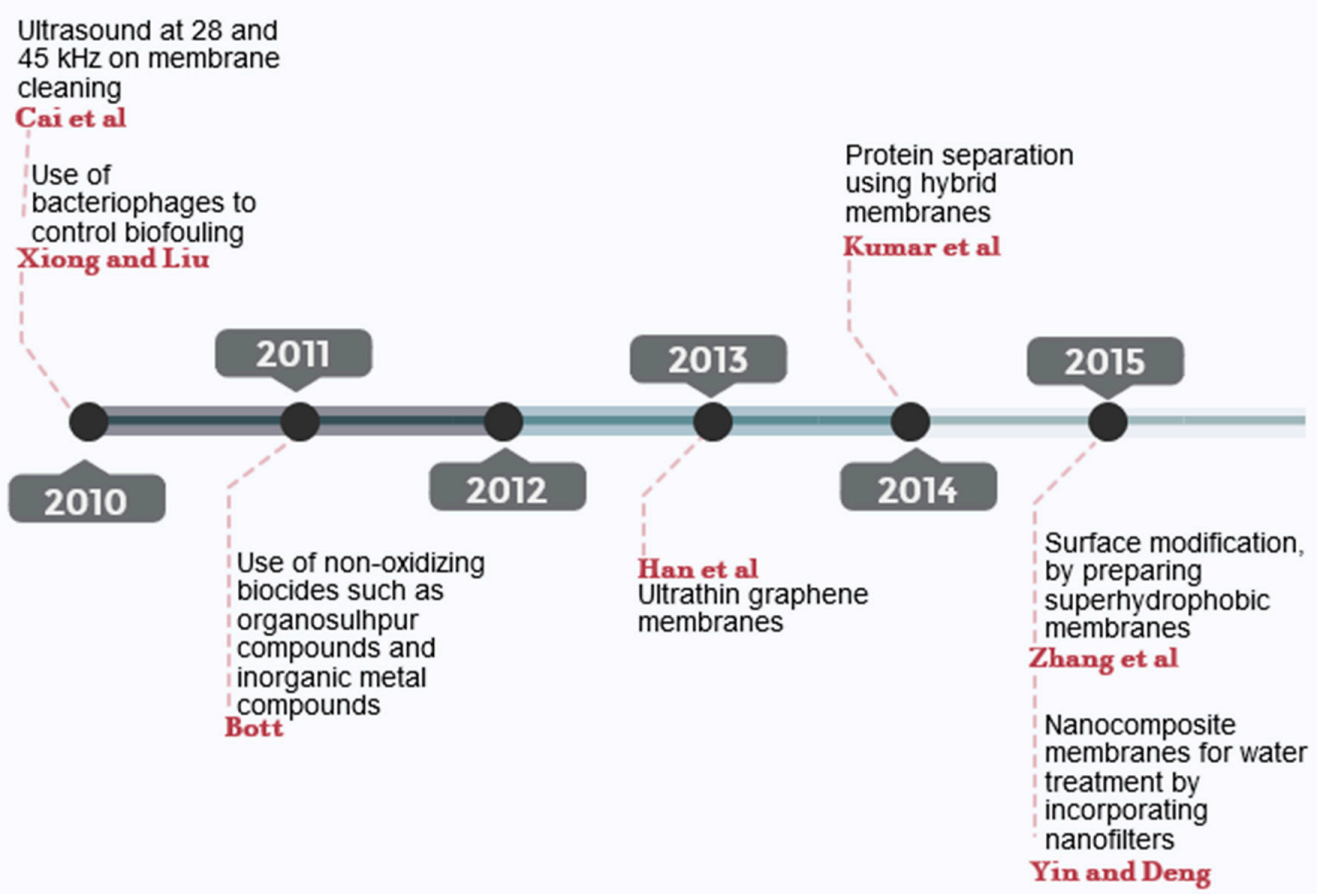

Figure 4. Milestones on the most recent studies on membrane fouling until 2015 [46-50].

An example of polymer blending is the modification of the conjugation of a polyvinyl alcohol membrane with gum arabic for water desalination. Such blending improved the membrane's performance by providing excellent permeation, salt rejection and biofouling resistance, also having more mechanical strength. The improvement was associated with the enhanced hydrophilicity due to the hydrophilic nature of gum arabic and its $\mathrm{OH}$ groups. When the surface is more hydrophilic, it displays more water affinity and prevents the adsorption of biofoulants. In this way, changes in hydrophilicity properties by polymer blending is a good approach to prepare a membrane surface with better biofouling resistant properties [51].

Carretier et al. [45] explored the synthesis of a triblock polymer. The used polymers were one block of styrene and two of ethylene glycol. The resulting polymer was achieved to improve the hydrophilicity of the membrane, and consequently, inhibit biofouling in dynamic conditions for three water filtration cycles. However, one of its disadvantages relies on the difficulty in controlling the membrane formation mechanisms when another material is added. Likewise, the lack is related to the stability of the membrane when it has surface modifiers. Despite this, authors still believed these membranes could be promising methods for water treatment and even blood filtration. To date, there are several types of commercial polymers that have been modified aimed at the improvement of their physico-chemical properties. For instance, polyethersulfone (PES)/cellulose acetate phthalate blends were used for the manufacture of ultrafiltration membranes [52]. Such membranes were fabricated by phase inversion-induced, and using polyvinylpyrrolidone as a pore former. The aim was to improve the hydrophilicity of the PES membrane by using cellulose acetate phthalate. By analyzing the water contact angle measurements, the results concluded that the hydrophilicities of blend membranes were enhanced, and such hydrophilic properties were increased by increasing the cellulose acetate phthalate concentration in the casting solution.

Finally, the authors suggested that cellulose acetate phthalate could play a role as an antifouling agent. More recently, Ma et al. [53] proposed another commercial polymer, like poly(vinylidene fluoride) (PVDF), to evaluate the antifouling properties by blending with synthesized amphiphilic poly(poly(ethylene glycol) methyl ether methacrylate-methyl methacrylate) [P(PEGMA-MMA)] copolymers with different initial PEGMA/MMA monomer ratios and PEG side chain lengths. After analysis, it was found that the higher O/C ratio in PEGMA (900) comprised more hydrophilic groups 
on the surface of the blend membranes and thus enhanced interaction with water molecules. In general, the water molecules released stronger hydration on the membrane surface, and therefore reduced the propensity of foulants to interact with the membrane surface [53]. At the end, the authors stated that the antifouling properties were dependent on the membrane surface hydrophilicity of the copolymer.

Improved antifouling properties on PES membranes by blending the amphiphilic surface modifier with crosslinked hydrophobic segments was reported by Liu et al. [54]. The amphiphilic modifier (MF-g-PEGn) was carried out by etherification of melamine formaldehyde prepolymer with PEG, and later blended in PES polymer to fabricate membranes by means of a nonsolvent induced phase separation method. These blend membranes (MF-g-PEGn) demonstrated a superior antifouling property due to the surface segregation of the hydrophilic polyethylene oxide (PEO). Interestingly, during the filtration testing, the flux recovery ratios after bovine serum albumin (BSA) separation of the PES control membrane and PES/MF-g-PEG6000 (0.36 wt. \%) were about 70.8\% and 91.6\%, respectively. All membranes displayed 100\% rejection efficiency. The pure water fluxes were enhanced from $60.7 \mathrm{~L} \mathrm{~m}^{-2} \mathrm{~h}^{-1}$ for the pristine PES membrane to $164.7 \mathrm{~L} \mathrm{~m}^{-2} \mathrm{~h}^{-1}$ for PES/MF-g-PEG6000 (0.36 wt. \%) [54]. Besides the study reported by Liu et al. [54], there have been other researchers interested in developing the amphiphilic surfaces on UF membranes with different antifouling mechanisms [55]. Ruan et al. [55], reported the fabrication of an amphiphilic NF membrane by a two-step surface modification of a polyamide NF membrane, that implements two mechanisms, one of them was the fouling resistance defense while the other was the fouling release defense. The experiments were performed with BSA solution, HA solution and SA solution; they showed that this modified membrane displayed a better antifouling property than the pristine one, i.e., polyamide NF membrane. Gao et al. [56], also carried out a study of modified PES membranes by incorporating the amphiphilic comb copolymer, where the modified membranes had a very low flux decline rate $(15.6 \%)$ and the flux recovery rate was up to $96.6 \%$; in addition, Gao concluded that the modified membrane had a stable and durable antifouling property after three cycles of BSA filtration [56]. As a preliminary conclusion of this section, the polymer blending generally aims to shift of the nature of the polymers to a more hydrophilic one which does not favor the interaction of foulants and the membrane surface.

\subsection{Nanocomposite Materials}

In addition to the polymer blending, the preparation of nanocomposite membranes is also a new trend on preparing membranes with better antifouling properties. A nanocomposite membrane is defined as the next generation of advanced membranes, in which nanomaterials are embedded and ideally well dispersed into a polymer matrix [57]. This concept of membranes has received great attention over the recent years. Typically, a composite membrane, as well as a mixed matrix membrane, combines the strengths of a polymer and inorganic materials to ideally reach a synergistic effect [58]. In principle, the embedding of nanomaterials into polymers can modify the structure, as well as physico-chemical properties of membranes, such as hydrophilicity, porosity, roughness, pore morphology, charge density, thermal, chemical, and mechanical stability. However, some important properties can also be enhanced, including flux permeation, foulant rejection, and antifouling properties $[14,59,60]$. For instance, Table 4 reports some examples of nanomaterials that have been incorporated into polymers, and their effect on the resulting membranes. Nowadays, considering the advancement of nanotechnology, nanomaterials represent a novel opportunity to mitigate biofouling. One of their greatest advantages is that they provide durability under high operating pressure conditions. In recent years, various porous nanomaterials were categorized as a new class of additives in the membranes. To date, several types of inorganic nanomaterials have been embedded in polymer membranes, such as zeolites [61], metal-organic frameworks (MOFs) [62], carbon nanotubes (CNTs) [63], porous organic cages (POCs) [64], silicas (mesoporous MCM-41) [65], graphene oxide (GO) [66], MOF-silica hybrid particles [67], titanium dioxide $\left(\mathrm{TiO}_{2}\right)$ [68], magnesium oxide [69] and Ag-based particles [70]. All these materials possess specific intrinsic features that enable them to provide enhanced properties to composite membranes. e.g., zeolites present competitive adsorption and diffusion properties, and cation exchange behavior in desalination processes. $\mathrm{TiO}_{2}$ can alter 
the membrane structure; for example, Ong et al. [60] mentioned that the use of titanium dioxide nanoparticles exhibited great results by improving the substrate properties instead of modifying the layer properties. Both $\mathrm{TiO}_{2}$ and silver particles offer the possibility of tuning the hydrophilicity of the membranes, as well as increase their porosity. In 2015, Homayoonfal et al. [71] showed that when using polysulfide/alumina nanocomposite membranes for bioreactors, the water flux could be increased while the membrane fouling was reduced by $83 \%$. Alumina nanoparticles were specifically synthesized by the co-precipitation method and their homogenous dispersion was carried by an ultrasonic bath. The authors concluded that the nanoparticles had a strong influence on the surface properties [70].

Over the last decade, graphene-based materials have attracted special attention for different types of applications. Such two-dimensional materials can elevate the surface area and weight ratio, giving a great mechanical and thermal stability to the membranes. Graphene oxide (GO) is especially preferred due to its hydrophilic nature, owing to the presence of polar hydroxyl and carboxyl groups [72]. GO has certainly been used in the fabrication of nanocomposite membranes for water treatment, including water desalination, removal of toxic ions and organic molecules in polluted water. There is evidence that carbon nanotubes, GO and other carbon allotropes can provide better antifouling and antioxidative properties than normal polyamide membranes, suggesting that when incorporating functionalized multi-walled carbon nanotubes, membrane performance is also improved $[72,73]$.

Table 4. Nanomaterials embedded in composite membranes for water treatment.

\begin{tabular}{|c|c|c|c|}
\hline Nanomaterial & Polymer & Remark of the Study & Reference \\
\hline $\mathrm{TiO}_{2}$ & Polyamide (PA) & $\begin{array}{l}\text { Good flux recovery by incorporating } \mathrm{TiO}_{2} \text {. Enhanced foulant } \\
\text { removal than pristine membrane. }\end{array}$ & {$[60]$} \\
\hline $\mathrm{Al}_{2} \mathrm{O}_{3}$ & Polysulfone (PS) & $\begin{array}{l}\text { Water flux increase. } \\
\text { Membrane fouling was reduced by } 83 \% \text {. }\end{array}$ & {$[71]$} \\
\hline GO-Ag & $\begin{array}{l}\text { Thin-film } \\
\text { composite (TFC) }\end{array}$ & $\begin{array}{l}\text { Static antimicrobial assays showed a significant inhibition to the } \\
\text { attachment of Pseudomonas aeruginosa cells. }\end{array}$ & {$[74]$} \\
\hline $\mathrm{Cu}$ & $\begin{array}{l}\text { Thin-film } \\
\text { composite (TFC) }\end{array}$ & $\begin{array}{l}\text { The nanomaterial was deposited via spray- and spin-assisted } \\
\text { layer-by-layer. } \\
\text { The method was efficient and improved the distribution compared } \\
\text { to conventional dip coating techniques. } \\
\text { Cu nanoparticles improved the anti-biofouling properties. } \\
\text { Cu nanoparticles effectively inhibited the permeate flux reduction } \\
\text { caused by bacterial deposition. }\end{array}$ & {$[75]$} \\
\hline $\mathrm{NH}_{2}$-TNTs & Polyamide (PA) & $\begin{array}{l}\text { The water flux of the membrane was significantly increased. } \\
\text { The nanomaterial significantly mitigated the BSA fouling and } \\
\text { achieved a promising water flux recovery rate after rinsing. }\end{array}$ & {$[76]$} \\
\hline $\mathrm{Fe}_{3} \mathrm{O}_{4}$ & $\begin{array}{l}\text { Polyethersulfone } \\
\text { (PES) }\end{array}$ & $\begin{array}{c}\text { Iron oxide nanoparticles resulted in an increase in hydrophilicity } \\
\text { and growth in the membrane sub-layer porosity. } \\
\text { The pore radius was affected. }\end{array}$ & {$[77]$} \\
\hline Silver-based MOF & $\begin{array}{l}\text { Thin-film } \\
\text { composite (TFC) }\end{array}$ & $\begin{array}{l}\text { The MOF improved both the biocidal activity and the hydrophilicity } \\
\text { of the membrane active layer. } \\
\text { No effect was observed on the membrane selectivity. }\end{array}$ & {$[78]$} \\
\hline Silica/QA/POM & $\begin{array}{l}\text { Thin-film } \\
\text { composite (TFC) }\end{array}$ & $\begin{array}{l}\text { Membrane with } 0.2 \text { wt. \% nanoparticle incorporation showed } \\
\text { superior water flux in forward osmosis processes and minimal } \\
\text { increase in reverse salt flux. Moreover, enhanced antifouling } \\
\text { propensity toward BSA and sodium alginate foulant was noted. }\end{array}$ & [79] \\
\hline QAC/Carbon & $\begin{array}{l}\text { Polyvinylidene } \\
\text { Fluoride (PVDF) }\end{array}$ & $\begin{array}{l}\text { The introduction of Quatery Ammonium Compound assembled on } \\
\text { Carbon into polymeric membranes was an effective way to prepare } \\
\text { anti-biofouling membranes for water and wastewater treatment. }\end{array}$ & {$[80]$} \\
\hline $\mathrm{ZnO}$ & $\begin{array}{l}\text { Polyaniline } \\
\text { (PANI) }\end{array}$ & $\begin{array}{l}\text { The resulting membranes showed a good mechanical strength with } \\
\text { moderate elasticity. } \\
\text { The membranes showed good antifouling properties toward marine } \\
\text { bacteria } V \text {. harveyi and B. licheniformis. }\end{array}$ & [81] \\
\hline
\end{tabular}

Abbreviations: $\mathrm{TiO}_{2}$ : titanium oxide, $\mathrm{Al}_{2} \mathrm{O}_{3}$ : aluminium oxide, GO-Ag: Graphene Oxide with silver, $\mathrm{Cu}$ : Copper, $\mathrm{NH}_{2}$-TNTs: Amino functionalized titanate nanotubes, $\mathrm{Fe}_{3} \mathrm{O}_{4}$ : magnetite, GG/AO: Guar Gum with Aluminum oxide, Silver-based MOF: silver-based metal organic frameworks, Polyoxometalates: POM, QAC/carbon: Quaternary Ammonium compound with carbon, $\mathrm{ZnO}$ : Zinc Oxide. 
GO is also recognized as one of the most promising nano-sized materials that has been applied for the elimination of pharmaceuticals from water and wastewater [82]. Chang et al. [83] evaluated the synergistic influence of GO and polyvinylpyrrolidone (PVP) on the separation performance of PVDF membranes. It was demonstrated that the membrane hydrophilicity and the antifouling properties were enhanced by embedding GO into PVP. The authors reported that the enhancement was attributed to the formation of hydrogen bonds between PVP and GO. Besides improving the hydrophilicity of membranes; GO has been also identified as a potential candidate to enhance the water transport of membranes according to its unimpeded water permeation properties [83-85]. Finally, some other nanomaterials are also providing good insights to mitigate the fouling in membranes. Zinc oxide $(\mathrm{ZnO})$, as a multifunctional inorganic material, is particular due to its relevant physical and chemical properties, e.g., catalytic, antibacterial and bactericide activities. Moreover, this nanomaterial can absorb polar hydroxyl groups $(-\mathrm{OH})$ and its surface area is relatively higher than other inorganic materials [86]. When dealing with its use for preparing nanocomposite membranes, $\mathrm{ZnO}$ can enhance specific properties in polymers, including the hydrophilicity, mechanical and chemical properties [87]. The embedding of $\mathrm{ZnO}$ also results in the enhancement of the hydrophilicity of PES NF membranes, which gives higher permeabilities in ZnO-filled nanocomposite membranes. In addition, fouling resistance during the filtration of humic acid solutions has been documented [88]. As a final remark from this section, Figure 5 shows in particular the milestones of nanocomposite membranes over the last years.

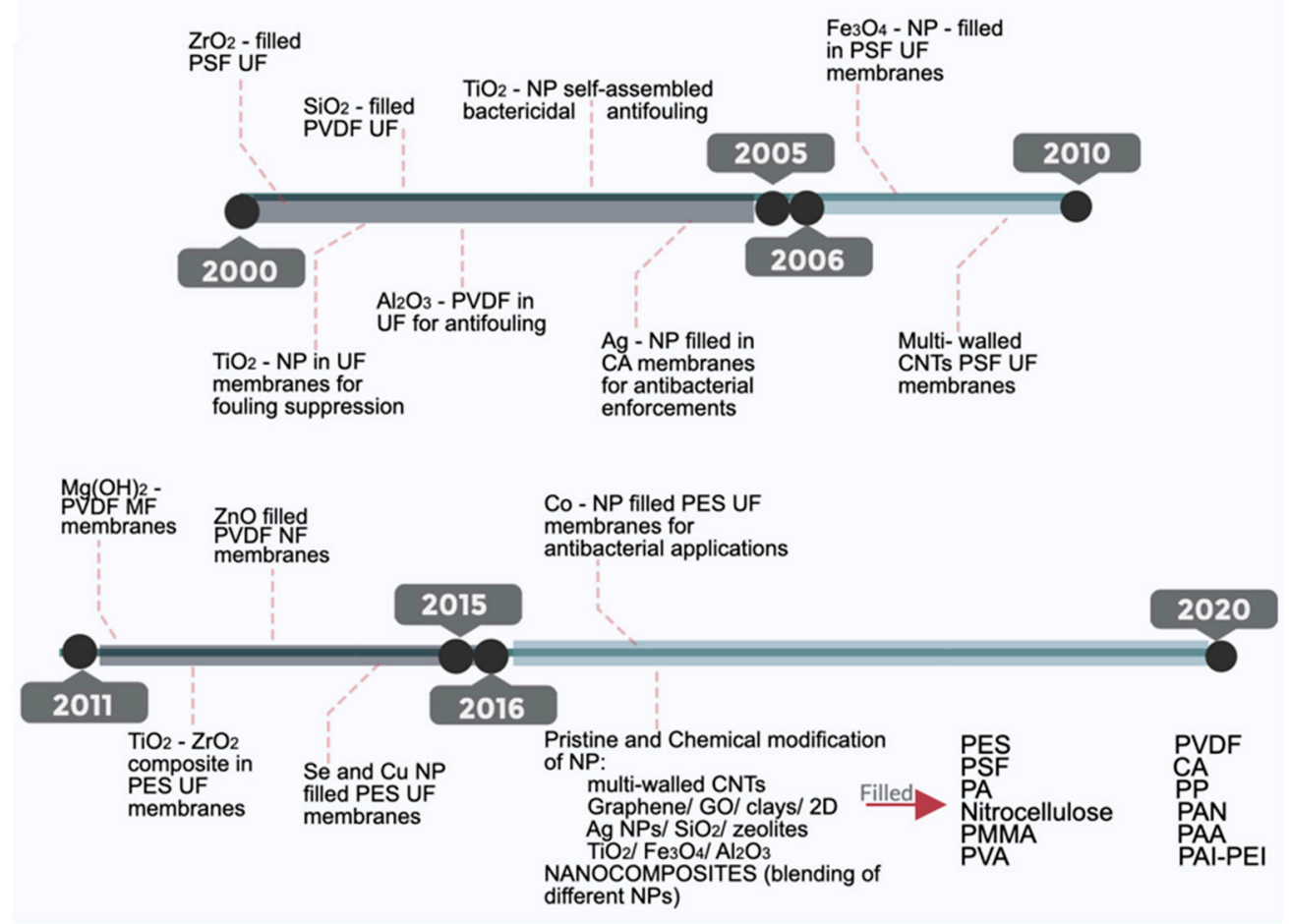

Figure 5. Milestones showing the progress of the nanocomposite membranes over the last 20 years.

\subsection{Chemical Modification}

Depending on the membrane material, the membrane surface of reverse osmosis, nanofiltration and ultrafiltration membranes is usually negatively charged according to the presence of sulfonic or carboxylic groups. These groups are relevant when using zwitterions, which are defined as molecules with two or more functional groups, in which at least one possesses a positive and one possesses a negative electrical charge, and consequently the net change of the entire molecule becomes zero [89]. In principle, when the foulant and the membrane display the same charge, specific forces, such as 
electrostatic repulsion, tend to appear, and the presence of such molecules reduces such a phenomenon. Few studies recognize some bacterial solutions carry negative charges, then if the membrane has a negative charge, there is less probability of showing bio-adhesion rather than if it is positively charged [14]. Based on this statement, the chemical modification of membranes via zwitterions has become a promising alternative. For example, Venault et al. [90] designed alternative copolymers of $\mathrm{p}$ (MAO-DMEA) (synthetized via the reaction between poly(maleic anhydride-alt-1-octadecene) and $\mathrm{N}, \mathrm{N}$-dimethylenediamine) and $\mathrm{p}(\mathrm{MAO}-\mathrm{DMPA})$ (synthetized via the reaction between poly-(maleic anhydride-alt-1-octadecene) and 3-(dimethylamino)-1-propylamine) of different carbon space length (CSL) using a ring-opening zwitterionization [90]. Such copolymers were later coated on poly (vinylidene fluoride) (PVDF) membranes by means of a self-assembled procedure. The authors studied the antifouling properties of the modified membranes treating several protein, cell, and bacterial assays, concluding that both zwitterionic modified membranes with different coating densities exhibited enhanced membrane hydrophilicity, and better resistance to blood cells, bacteria, platelet and protein adsorption. Over the course of this paper, we have mentioned that hydrophilicity is needed for the non-fouling behavior of an interface. Interestingly, the membranes prepared by Venault et al. [90] indicated that zwitterionic molecules enabled saturated surface hydration, which was in agreement with the higher contact angle measurements and hydration capacity of the membranes. This is, in fact, an impressive approach to preparing smart antifouling membranes. The use of antimicrobial membranes is able to inactivate bacterial cells at the contact by using a biocide, decreasing the rate of biofilm formation. Even though it is an efficient method, their long-term functionality was limited by the accumulation of dead cells; thereby, the best way to increase their efficiency was to design a membrane with both antimicrobial and antifouling properties [15].

It is important to point out that the cost of using chemical additives will definitely increase the membrane production cost but may also increase toxicity. Here, authors should start to evaluate the environmental implications in terms of possible release to the environment and discharge to the water. e.g., chlorine, as a typical biocide, is recognized as the most feasible due to its low cost and efficiency at low concentrations. However, it is under observation since organo-chloro compounds are a result of its use [91]. Table 5 enlists some examples of chemicals used for chemical modification, as well as their effect when used in membrane modifications.

Table 5. Chemicals used for chemical modification of membrane's surface.

\begin{tabular}{|c|c|c|}
\hline Material & Remarks & References \\
\hline Divalent Cations & $\begin{array}{l}\text { Calcium enhanced the fouling properties due to its bridging effects between } \\
\text { carboxylic active groups contained in NOM and the negatively charged } \\
\text { functional groups in the membrane surface. }\end{array}$ & [19] \\
\hline $\begin{array}{c}\text { Metal ions } \\
\left(\mathrm{Al}^{3+} \text { and } \mathrm{Fe}^{3+}\right)\end{array}$ & $\begin{array}{l}\text { They are being used to form large precipitating complexes with the Humic } \\
\text { acid and fulvic acid, and thus to facilitate their elimination. }\end{array}$ & [20] \\
\hline Sulfonic groups & $\begin{array}{l}\text { The attaching of sulfonic groups to the aromatic backbone of polysulfone and } \\
\text { polyethersulfone membranes generated an electrophilic aromatic substitution } \\
\text { reaction, in which hydrogen is replaced by sulfonic acid. }\end{array}$ & [92] \\
\hline Carboxylation & The presence of carboxylic groups increased the membrane hydrophilicity. & [92] \\
\hline $\begin{array}{l}\text { Plasma } \\
\text { treatment }\end{array}$ & $\begin{array}{c}\text { The bombarded surface of the membrane with ionized plasma components } \\
\text { generated radical sites. Active components generated by such plasma } \\
\text { contributed to increasing the hydrophilicity without affecting the bulk of } \\
\text { the polymer. }\end{array}$ & [92] \\
\hline $\mathrm{CO}_{2}$-plasma & $\begin{array}{l}\text { The addition of oxygen into the membrane' surface, in the form of carbonyl, } \\
\text { acid and ester groups, increased in hydrophilicity. }\end{array}$ & [92] \\
\hline D-Tyrosine & $\begin{array}{l}\text { D-amino acids inhibited the microbial attachment. } \\
\text { D-tyrosine enhanced the membrane hydrophilicity and provided a smoother } \\
\text { surface to the membrane without modifying its transport properties, and also } \\
\text { reduced the propensity for biofouling. }\end{array}$ & [93] \\
\hline
\end{tabular}


Table 5. Cont.

\begin{tabular}{ccc}
\hline Material & Remarks & References \\
\hline GO-pDA & $\begin{array}{c}\text { The attaching of graphene oxide nanosheets to the membrane surface, by } \\
\text { chemical modification with polydopamine through an oxidative } \\
\text { polymerization, reduced the loss of the draw solution and increased both } \\
\text { membrane water flux and biofouling resistance. }\end{array}$ & {$[94]$} \\
$\begin{array}{c}\text { Charged } \\
\text { hydrogel }\end{array}$ & $\begin{array}{c}\text { Anti-biofouling properties of neutral (polyHEMA-co-PEG10MA), cationic } \\
\text { (polyDMAEMA) and anionic (polySPMA) hydrogels in feed spacers were } \\
\text { tested with E. coli. }\end{array}$ & $\begin{array}{c}\text { The membranes showed reduced attachment and biofouling in the } \\
\text { spacer-filled channels, resulting in delayed biofilm growth. }\end{array}$ \\
\hline $\begin{array}{c}\text { Antimicrobial } \\
\text { peptides }\end{array}$ & $\begin{array}{c}\text { A polycyclic antimicrobial peptide, like nisin, decreased the viability of } \\
\text { Bacillus sp., and the dislodging of P. aeruginosa P60. }\end{array}$ & [96] \\
\hline
\end{tabular}

Of course, according to the mentioned risks, there is today's interest in alternative and new methods that do not imply the use of chemical additives. The next section addresses some other novel strategies to mitigate the fouling in membranes.

\subsection{Alternative Novel Strategies in Biofouling Mitigation}

In addition to membrane surface modification, polymer bending or composite membranes, the research community has directed the approaches of mitigating the fouling by applying appropriate preliminary treatments of the bulk feed. Conventionally, the pretreatments comprise different methods, including disinfection, coagulation flocculation, and a filtration process, where all of them aim to remove foulants or their precursors [14]. As an example, Katalo et al. [97] used Moringa oleifera seeds during pretreatment prior to microfiltration of river water. Moringa oleifera represents a non-toxic natural coagulant, which can be used in a conventional coagulation process. According to the authors' findings, the results of using this biomaterial can be comparable when using aluminum-based coagulants. Therefore, this approach not only represents a promising alternative in water treatment, but also its potentiality regards to the non-use of high-cost chemical coagulants, such as $\mathrm{Al}_{2}\left(\mathrm{SO}_{4}\right)_{3}$ and $\mathrm{FeCl}_{3}$. Moreover, the seeds contain dimeric cationic proteins that substantially reduced membrane fouling by removing suspended solids and dissolving organic matter [97].

During the review and current state-of-the-art provided by Gule et al. [47], several approaches to reducing biofouling have been addressed. Interestingly, one of them is proposing the limitation of the nutrients. Thereby, when the quantity of biodegradable dissolved organic carbon and assimilable organic carbon is reduced, even though the correlation between them does not exist, the biofouling is decreased. Additionally, the reduction of availability of phosphates in the bulk feed may limit the biofouling. Such a reduction could be done by ion exchange, precipitation, and electrochemical coagulation, which do not require the addition of chemicals, representing an environmentally friendly strategy [47]. The application of ultrasound is another approach which can also favor the cleaning of the membrane. There are many studies on the usage of this technique, which are dedicated to studying the cavitation waves and their effect. In theory, ultrasound produces physical phenomena, such as shock waves, acoustic streaming and microstreaming, which may help to release the particles from a fouled membrane. It is proven that at higher values of frequency and power intensity, the flow velocity increases and thus are better at detaching the foulants [98]. On the other hand, there are other physical cleaning methods that comprise the application of forces, such as mechanic and hydraulic, for the detachment of the foulants. Table 6 summarizes some of the novel and current strategies implemented by scientists aimed at the mitigation of biofouling in membranes. 
Table 6. Alternative novel approaches for biofouling mitigation.

\begin{tabular}{ccc}
\hline $\begin{array}{c}\text { Approach } \\
\begin{array}{c}\text { Addition of bacteriophages } \\
\text { as biocidal agents }\end{array}\end{array}$ & $\begin{array}{c}\text { T4 bacteriophage-facilitated biofouling control in the membrane } \\
\text { ultrafiltration to inhibit the propagation of E. coli in situ. }\end{array}$ & References \\
\hline Bio-electrochemistry & $\begin{array}{c}\text { Silver was bioelectrochemically recovered from wastewater. It is an } \\
\text { eco-friendly method showing the potential in anti-biofouling } \\
\text { applications with recovered nano-flakes, particularly in membrane } \\
\text { bioreactors. }\end{array}$ & {$[100]$} \\
Quorum quenching & $\begin{array}{c}\text { The quorum quenching caused to prevent biofouling since quorum } \\
\text { sensing interrupts the biological communication mechanism } \\
\text { between microorganisms. This was achieved with rotational } \\
\text { membrane filtration modules }\end{array}$ & [101] \\
\hline UV light & $\begin{array}{c}\text { Ultraviolet (UV) light penetrates the cell wall and damages the DNA } \\
\text { and RNA, thus stopping the microorganism from reproducing. } \\
\text { Furthermore, the main advantage is that it does not produce } \\
\text { chemical by-products that can affect health. }\end{array}$ & [102] \\
\hline Metazoans & $\begin{array}{c}\text { The presence of an oligochaete (Aelosoma hemprichi), and a nematode } \\
\text { (Plectus aquatilis) strongly affected the formation of biofilm. }\end{array}$ & [103] \\
\hline
\end{tabular}

It is well known that static mixers can be an effective and efficient way to reduce membrane fouling since they divert the fluid, which provokes the increase of the shear rate at the membrane surface. This enhances the back-transport of retained matter. Nevertheless, this implementation of mixers within the flow channel of a membrane implies an extra pressure drop. To diminish this effect, the group of Professor Wessling very recently developed the shortened and twisted tape mixers (see Figure 6) and analyzed the way shortening was translated into the reduction of fouling mitigation.

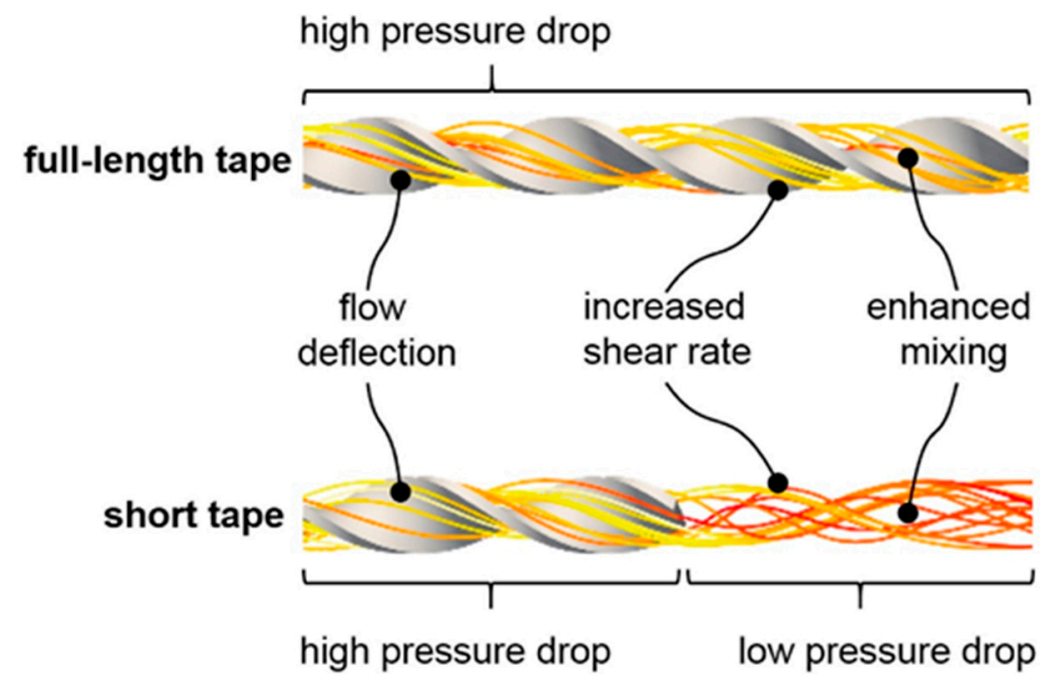

Figure 6. Shortening and spaced twisted tapes in tubular membranes aimed at biofouling mitigation [104].

In such a proposal, they followed the following stages: (i) short total length of the twisted tape, subsequently (ii) the use of spaced short twisted tape elements, which were maintained at their location by smooth rods placed between the twisted elements. As interesting findings, the selection of modified tape mixers presented with lower pressure loss, but enough flow properties toward fouling mitigation [104]. In addition, the influence of foulant concentration in this approach was studied by the authors, who found out that for low silica concentrations (in the range of $0.03 \mathrm{~g} / \mathrm{L}$ ), the short and space twisted tapes mitigated fouling were as similar as the full-length twisted tape. While at high 
silica concentrations and fluxes, the full-length mixer decreased the fouling and was even stronger than the short and spaced twisted tapes.

\section{Concluding Remarks and Future Trends in the Field}

Over the course of this paper, we have reviewed the milestones of the research community focused on the strategies and approaches to face the fouling phenomenon on membranes, which in fact, is the primary drawback of pressure-driven membrane processes. Several approaches to preventing the adhesion of matter, translated to biofouling on membranes deals with the shift of their physico-chemical properties. In general, the preparation of highly hydrophilic membranes is sought using different approaches, including the preparation of nanocomposite membranes, membrane modification, and polymer blending. However, diverse options have also come out to be more effective in the removal of organic matter, e.g., combination of different techniques, resulting in efficient strategies for fouling mitigation. Nowadays, it is likely that the concept of nanocomposite membranes is the most explored approach, which comprises the embedding of nanomaterials (including clays, zeolites, metal oxides, graphene-based materials, carbon nanotubes, metal-organic frameworks, to mention just a few) into the polymer matrix. To obtain high performing membranes (in terms of permeation and rejection) with better antifouling resistance, herein, it is crucial the right selection of the nanomaterials according to their intrinsic properties, such as type of material, surface charge, composition, surface area, size, material loading, hydrophilic/hydrophobic nature, among others. However, the type of polymer and its compatibility will also play an important factor not only in the performance but also in the fabrication of the membranes. Even though there are already great advances in the field, there is still a strong need to work on the enhancement of the intrinsic properties of the membrane surface, including hydrophilicity and electrical surface charge, to improve the antifouling/biofouling and antimicrobial properties of membranes. Moreover, it is recommended to new researchers in the field the analysis of the separation performance and biofouling properties of the novel membranes using real complex solutions (such as industrial by-products and wastewaters). In this sense, the developed membranes can provide more realistic insights, which may give a clear overview of the potentiality of those membranes in water treatment applications.

Author Contributions: D.P.-R., Z.P.G.-A. and A.Z.-R. wrote the original draft paper. R.C.-M. conceived, designed, reviewed and edited the manuscript. All authors have read and agreed to the published version of the manuscript.

Funding: This research received no external funding.

Acknowledgments: R. Castro-Muñoz acknowledges the School of Engineering and Science and the FEMSA-Biotechnology Center at Tecnológico de Monterrey for their support through the Bioprocess (0020209I13) Focus Group.

Conflicts of Interest: The authors declare no conflicts of interest.

\section{References}

1. Castro-Muñoz, R. Pressure-driven membrane processes involved in waste management in agro-food industries: A viewpoint. AIMS Energy 2018, 6, 1025-1031. [CrossRef]

2. Galanakis, C.M.; Cvejic, J.; Verardo, V.; Segura-Carretero, A. Food Use for Social Innovation by Optimizing Food Waste Recovery Strategies. In Innovation Strategies in the Food Industry: Tools for Implementation; Academic Press: Cambridge, MA, USA, 2016. [CrossRef]

3. Liu, B.; Wang, D.; Yu, G.; Meng, X.; David Giraldo, J.; Thakur, V.K.; Gutiérrez, E. The History and State of Art in Membrane Technologies Tarragona, Erasmus 2005. J. Membr. Sci. 2013, 16, 1-28. [CrossRef]

4. Kabsch-Korbutowicz, M.; Kutylowska, M. The Possibilities of Modelling the Membrane Separation Processes. Environ. Prot. Eng. 2008, 34, 15.

5. Kayvani Fard, A.; McKay, G.; Buekenhoudt, A.; Al Sulaiti, H.; Motmans, F.; Khraisheh, M.; Atieh, M. Inorganic membranes: Preparation and application for water treatment and desalination. Materials 2018, 11, 74. [CrossRef] 
6. Goh, P.S.; Ismail, A.F. A review on inorganic membranes for desalination and wastewater treatment. Desalination 2018, 434, 60-80. [CrossRef]

7. Castro-Muñoz, R.; Barragán-Huerta, B.E.; Fíla, V.; Denis, P.C.; Ruby-Figueroa, R. Current role of membrane technology: From the treatment of agro-industrial by-products up to the valorization of valuable compounds. Waste Biomass Valorization 2018, 9, 513-529. [CrossRef]

8. Madaeni, S.S.; Zinadini, S.; Vatanpour, V. A new approach to improve antifouling property of PVDF membrane using in situ polymerization of PAA functionalized $\mathrm{TiO} 2$ nanoparticles. J. Membr. Sci. 2011, 380, 155-162. [CrossRef]

9. Ursino, C.; Castro-Muñoz, R.; Drioli, E.; Gzara, L.; Albeirutty, M.; Figoli, A. Progress of Nanocomposite Membranes for Water Treatment. Membranes 2018, 8, 18. [CrossRef]

10. Nguyen, T.; Roddick, F.A.; Fan, L. Biofouling of water treatment membranes: A review of the underlying causes, monitoring techniques and control measures. Membranes 2012, 2, 804-840. [CrossRef] [PubMed]

11. Ozzello, E.; Mollea, C.; Bosco, F.; Bongiovanni, R. Factors Influencing Biofouling and Use of Polymeric Materials to Mitigate It. Adhes. Pharm. Biomed. Dent. Fields 2017, 185-206. [CrossRef]

12. Kirschner, A.Y.; Cheng, Y.H.; Paul, D.R.; Field, R.W.; Freeman, B.D. Fouling mechanisms in constant flux crossflow ultrafiltration. J. Membr. Sci. 2019, 574, 65-75. [CrossRef]

13. Goh, P.S.; Lau, W.J.; Othman, M.H.D.; Ismail, A.F. Membrane fouling in desalination and its mitigation strategies. Desalination 2018, 425, 130-155. [CrossRef]

14. Kochkodan, V.; Hilal, N. A comprehensive review on surface modified polymer membranes for biofouling mitigation. Desalination 2015, 356, 187-207. [CrossRef]

15. Perreault, F.; Jaramillo, H.; Xie, M.; Ude, M.; Nghiem, L.D.; Elimelech, M. Biofouling Mitigation in Forward Osmosis Using Graphene Oxide Functionalized Thin-Film Composite Membranes. Environ. Sci. Technol. 2016, 50, 5840-5848. [CrossRef]

16. Zheng, Y.; Zhang, W.; Tang, B.; Ding, J.; Zheng, Y.; Zhang, Z. Membrane fouling mechanism of biofilm-membrane bioreactor (BF-MBR): Pore blocking model and membrane cleaning. Bioresour. Technol. 2018, 250, 398-405. [CrossRef]

17. Said, M.; Ahmad, A.; Mohammad, A.W.; Nor, M.T.M.; Sheikh Abdullah, S.R. Blocking mechanism of PES membrane during ultrafiltration of POME. J. Ind. Eng. Chem. 2015, 21, 182-188. [CrossRef]

18. Castro-Muñoz, R.; Conidi, C.; Cassano, A. Membrane-based technologies for meeting the recovery of biologically active compounds from foods and their by-products. Crit. Rev. Food Sci. Nutr. 2019, 59, 2927-2948. [CrossRef]

19. Zheng, X. Major Organic Foulants in Ultrafiltration of Treated Domestic Wastewater and their Removal by Bio-Filtration as Pre-Treatment. Doctoral Thesis, Technische Universität Berlin, Berlin, Germany, 2010.

20. Abdul Ghani, D.; Radwan, A.-R.; Mohammad, J. Studies on organic foulants in the seawater feed of reverse osmosis plants of SWCC. Desalination 2000, 132, 217-232.

21. Maartens, A.; Swart, P.; Jacobs, E.P. Feed-water pretreatment: Methods to reduce membrane fouling by natural organic matter. J. Membr. Sci. 1999, 163, 51-62. [CrossRef]

22. Jepsen, K.L.; Bram, M.V.; Pedersen, S.; Yang, Z. Membrane fouling for produced water treatment: A review study from a process control perspective. Water (Switzerland) 2018, 10, 847. [CrossRef]

23. Cassano, A.; Conidi, C.; Ruby-Figueroa, R.; Castro-Muñoz, R. Nanofiltration and tight ultrafiltration membranes for the recovery of polyphenols from agro-food by-products. Int. J. Mol. Sci. 2018, 19, 351. [CrossRef] [PubMed]

24. He, Y.; Li, G.; Wang, H.; Zhao, J.; Su, H.; Huang, Q. Effect of operating conditions on separation performance of reactive dye solution with membrane process. J. Membr. Sci. 2008, 321, 183-189. [CrossRef]

25. Nanda, D.; Tung, K.L.; Li, Y.L.; Lin, N.J.; Chuang, C.J. Effect of pH on membrane morphology, fouling potential, and filtration performance of nanofiltration membrane for water softening. J. Membr. Sci. 2010, 349, 411-420. [CrossRef]

26. Franks, R.; Bartels, C.; Nagghappan, L.N.S.P. Performance of a reverse osmosis system when reclaiming high $\mathrm{Ph}$-High temperature wastewater. In Proceedings of the 2009 AWWA Membrane Technology Conference and Exposition, Memphis, TN, USA, 15-18 March 2009; pp. 1-16.

27. Kucera, J. Biofouling of polyamide membranes: Fouling mechanisms, current mitigation and cleaning strategies, and future prospects. Membranes 2019, 9, 111. [CrossRef] 
28. Koo, C.H.; Mohammad, A.W.; Suja', F. Effect of cross-flow velocity on membrane filtration performance in relation to membrane properties. Desalin. Water Treat. 2015, 55, 678-692. [CrossRef]

29. Choi, H.; Zhang, K.; Dionysiou, D.D.; Oerther, D.B.; Sorial, G.A. Effect of permeate flux and tangential flow on membrane fouling for wastewater treatment. Sep. Purif. Technol. 2005, 45, 68-78. [CrossRef]

30. Rezaei, H.; Ashtiani, F.Z.; Fouladitajar, A. Fouling behavior and performance of microfiltration membranes for whey treatment in steady and unsteady-state conditions. Braz. J. Chem. Eng. 2014, 31, 503-518. [CrossRef]

31. Jin, X.; Jawor, A.; Kim, S.; Hoek, E.M.V. Effects of feed water temperature on separation performance and organic fouling of brackish water RO membranes. Desalination 2009, 239, 346-359. [CrossRef]

32. Wong, P.C.Y.; Kwon, Y.N.; Criddle, C.S. Use of atomic force microscopy and fractal geometry to characterize the roughness of nano-, micro-, and ultrafiltration membranes. J. Membr. Sci. 2009, 340, 117-132. [CrossRef]

33. Costa, A.R.; de Pinho, M.N.; Elimelech, M. Mechanisms of colloidal natural organic matter fouling in ultrafiltration. J. Membr. Sci. 2006, 281, 716-725. [CrossRef]

34. Li, Q.; Xu, Z.; Pinnau, I. Fouling of reverse osmosis membranes by biopolymers in wastewater secondary effluent: Role of membrane surface properties and initial permeate flux. J. Membr. Sci. 2007, 290, 173-181. [CrossRef]

35. Xu, H.; Liu, Y. Control and cleaning of membrane biofouling by energy uncoupling and cellular communication. Environ. Sci. Technol. 2011, 45, 595-601. [CrossRef] [PubMed]

36. Durham, B.; Walton, A. Membrane pretreatment of reverse osmosis: Long-term experience on difficult waters. Desalination 1999, 122, 157-170. [CrossRef]

37. Amjad, Z. RO systems current fouling problems \& solutions. Desalin. Water Reuse 1997, 6, 55-60.

38. Isaias, N.P. Experience in reverse osmosis pretreatment. Desalination 2001, 139, 57-64. [CrossRef]

39. Khawaji, A.D.; Kutubkhanah, I.K.; Wie, J.M. Advances in seawater desalination technologies. Desalination 2008, 221, 47-69. [CrossRef]

40. Abu Tarboush, B.J.; Rana, D.; Matsuura, T.; Arafat, H.A.; Narbaitz, R.M. Preparation of thin-film-composite polyamide membranes for desalination using novel hydrophilic surface modifying macromolecules. J. Membr. Sci. 2008, 325, 166-175. [CrossRef]

41. Vikesland, P.J.; Valentine, R.L. Modeling the kinetics of ferrous iron oxidation by monochloramine. Environ. Sci. Technol. 2002, 36, 662-668. [CrossRef]

42. Porcelli, N.; Judd, S. Chemical cleaning of potable water membranes: A review. Sep. Purif. Technol. 2010, 71, 137-143. [CrossRef]

43. Surface, E.; Treatment, W. Committee Report: Recent advances and research needs in membrane fouling. J. Am. Water Work. Assoc. 2005, 97, 79-89. [CrossRef]

44. Le-Clech, P.; Chen, V.; Fane, T.A.G. Fouling in membrane bioreactors used in wastewater treatment. J. Membr. Sci. 2006, 284, 17-53. [CrossRef]

45. Carretier, S.; Chen, L.A.; Venault, A.; Yang, Z.R.; Aimar, P.; Chang, Y. Design of PVDF/PEGMA-b-PS-b-PEGMA membranes by VIPS for improved biofouling mitigation. J. Membr. Sci. 2016, 510, 355-369. [CrossRef]

46. Cai, M.; Zhao, S.; Liang, H. Mechanisms for the enhancement of ultrafiltration and membrane cleaning by different ultrasonic frequencies. Desalination 2010, 263, 133-138. [CrossRef]

47. Gule, N.P.; Begum, N.M.; Klumperman, B. Advances in biofouling mitigation: A review. Crit. Rev. Environ. Sci. Technol. 2016, 46, 535-555. [CrossRef]

48. Homaeigohar, S.; Elbahri, M. Graphene membranes for water desalination. NPG Asia Mater. 2017,9 , e427. [CrossRef]

49. Solís Carvajal, C.A.; Vélez Pasos, C.A.; Ramírez-Navas, J.S. Tecnología de membranas: Ultrafiltración. Entre Cienc. E Ing. 2017, 11, 26-36. [CrossRef]

50. Yin, J.; Deng, B. Polymer-matrix nanocomposite membranes for water treatment. J. Membr. Sci. 2015, 479, 256-275. [CrossRef]

51. Falath, W.; Sabir, A.; Jacob, K.I. Novel reverse osmosis membranes composed of modified PVA/Gum Arabic conjugates: Biofouling mitigation and chlorine resistance enhancement. Carbohydr. Polym. 2017, 155, 28-39. [CrossRef]

52. Rahimpour, A.; Madaeni, S.S. Polyethersulfone (PES)/cellulose acetate phthalate (CAP) blend ultrafiltration membranes: Preparation, morphology, performance and antifouling properties. J. Membr. Sci. 2007, 305, 299-312. [CrossRef] 
53. Ma Wenzhong Rajabzadeh, S.; Shaikh, A.R.; Kakihana, Y.; Sun, Y.; Matsuyama, H. Effect of type of poly(ethylene glycol) (PEG) based amphiphilic copolymer on antifouling properties of copolymer/poly (vinylidene fluoride) (PVDF) blend membranes. J. Membr. Sci. 2016, 514, 429-439. [CrossRef]

54. Liu, Y.; Su, Y.; Zhao, X.; Li, Y.; Zhang, R.; Jiang, Z. Improved antifouling properties of polyethersulfone membrane by blending the amphiphilic surface modifier with crosslinked hydrophobic segments. J. Membr. Sci. 2015, 486, 195-206. [CrossRef]

55. Ruan, H.; Li, B.; Ji, J.; Sotto, A.; Van Der Bruggen, B.; Shen, J.; Gao, C. Preparation and characterization of an amphiphilic polyamide nanofiltration membrane with improved antifouling properties by two-step surface modification method. RSC Adv. 2018, 8, 13353-13363. [CrossRef]

56. Gao, F.; Zhang, G.; Zhang, Q.; Zhan, X.; Chen, F. Improved Antifouling Properties of Poly(Ether Sulfone) Membrane by Incorporating the Amphiphilic Comb Copolymer with Mixed Poly(Ethylene Glycol) and Poly(Dimethylsiloxane) Brushes. Ind. Eng. Chem. Res. 2015, 54, 8789-8800. [CrossRef]

57. Castro-Muñoz, R.; Fíla, V. Progress on incorporating zeolites in matrimid@5218 mixed matrix membranes towards gas separation. Membranes 2018, 8, 30. [CrossRef] [PubMed]

58. Castro-Muñoz, R.; De La Iglesia, Ó.; Fila, V.; Téllez, C.; Coronas, J. Pervaporation-assisted esterification reactions by means of mixed matrix membranes. Ind. Eng. Chem. Res. 2018, 57. [CrossRef]

59. Esfahani, M.R.; Aktij, S.A.; Dabaghian, Z.; Firouzjaei, M.D.; Rahimpour, A.; Eke, J.; Escobar, I.C.; Abolhassani, M.; Greenlee, L.F.; Esfahani, A.R.; et al. Nanocomposite membranes for water separation and purification: Fabrication, modification, and applications. Sep. Purif. Technol. 2019, 213, 465-499. [CrossRef]

60. Ong, C.S.; Goh, P.S.; Lau, W.J.; Misdan, N.; Ismail, A.F. Nanomaterials for biofouling and scaling mitigation of thin film composite membrane: A review. Desalination 2016, 393, 2-15. [CrossRef]

61. Zhu, B.; Myat, D.T.; Shin, J.W.; Na, Y.H.; Moon, I.S.; Connor, G.; Maeda, S.; Morris, G.; Gray, S.; Duke, M. Application of robust MFI-type zeolite membrane for desalination of saline wastewater. J. Membr. Sci. 2015, 475, 167-174. [CrossRef]

62. Gao, R.; Zhang, Q.; Lv, R.; Soyekwo, F.; Zhu, A.; Liu, Q. Highly efficient polymer-MOF nanocomposite membrane for pervaporation separation of water/methanol/MTBE ternary mixture. Chem. Eng. Res. Des. 2017, 117, 688-697. [CrossRef]

63. Khalid, A.; Abdel-Karim, A.; Ali Atieh, M.; Javed, S.; McKay, G. PEG-CNTs nanocomposite PSU membranes for wastewater treatment by membrane bioreactor. Sep. Purif. Technol. 2018, 190, 165-176. [CrossRef]

64. María Arsuaga, J.; Sotto, A.; del Rosario, G.; Martínez, A.; Molina, S.; Teli, S.B.; de Abajo, J. Influence of the type, size, and distribution of metal oxide particles on the properties of nanocomposite ultrafiltration membranes. J. Membr. Sci. 2013, 428, 131-141. [CrossRef]

65. Wang, L.; Han, X.; Li, J.; Zheng, D.; Qin, L. Modified MCM-41 silica spheres filled polydimethylsiloxane membrane for dimethylcarbonate/methanol separation via pervaporation. J. Appl. Polym. Sci. 2013, 127, 4662-4671. [CrossRef]

66. Sun, X.; Qin, J.; Xia, P.; Guo, B.; Yang, C.; Song, C.; Wang, S. Graphene oxide-Silver nanoparticle membrane for biofouling control and water purification. Chem. Eng. J. 2015, 281, 53-59. [CrossRef]

67. Huang, J.; Zhang, K.; Wang, K.; Xie, Z.; Ladewig, B.; Wang, H. Fabrication of polyethersulfone-mesoporous silica nanocomposite ultrafiltration membranes with antifouling properties. J. Membr. Sci.. [CrossRef]

68. Sotto, A.; Boromand, A.; Balta, S.; Darvishmanash, S.; Kim, J.; Van der Bruggen, B. Nanofiltration membranes enhanced with TiO 2 nanoparticles: A comprehensive study. Desalin. Water Treat. 2011, 34, 179-183. [CrossRef]

69. Matteucci, S.; Kusuma, V.A.; Kelman, S.D.; Freeman, B.D. Gas transport properties of MgO filled poly(1-trimethylsilyl-1-propyne) nanocomposites. Polymer 2008, 49, 1659-1675. [CrossRef]

70. Yang, Z.; Wu, Y.; Wang, J.; Cao, B.; Tang, C.Y. In situ reduction of silver by polydopamine: A novel antimicrobial modification of a thin-film composite polyamide membrane. Environ. Sci. Technol. 2016, 50, 9543-9550. [CrossRef]

71. Homayoonfal, M.; Mehrnia, M.R.; Rahmani, S.; Mohades Mojtahedi, Y. Fabrication of alumina/polysulfone nanocomposite membranes with biofouling mitigation approach in membrane bioreactors. J. Ind. Eng. Chem. 2015, 22, 357-367. [CrossRef]

72. Jhaveri, J.H.; Murthy, Z.V.P. A comprehensive review on anti-fouling nanocomposite membranes for pressure driven membrane separation processes. Desalination 2016, 379, 137-154. [CrossRef] 
73. Zhao, H.; Qiu, S.; Wu, L.; Zhang, L.; Chen, H.; Gao, C. Improving the performance of polyamide reverse osmosis membrane by incorporation of modified multi-walled carbon nanotubes. J. Membr. Sci. 2014, 450, 249-256. [CrossRef]

74. Faria, A.F.; Liu, C.; Xie, M.; Perreault, F.; Nghiem, L.D.; Ma, J.; Elimelech, M. Thin-film composite forward osmosis membranes functionalized with graphene oxide-silver nanocomposites for biofouling control. J. Membr. Sci. 2017, 525, 146-156. [CrossRef]

75. Ma Wen Soroush, A.; Van Anh Luong, T.; Brennan, G.; Rahaman, M.S.; Asadishad, B.; Tufenkji, N. Sprayand spin-assisted layer-by-layer assembly of copper nanoparticles on thin-film composite reverse osmosis membrane for biofouling mitigation. Water Res. 2016, 99, 188-199. [CrossRef]

76. Emadzadeh, D.; Lau, W.J.; Rahbari-Sisakht, M.; Daneshfar, A.; Ghanbari, M.; Mayahi, A.; Matsuura, T.; Ismail, A.F. A novel thin film nanocomposite reverse osmosis membrane with superior anti-organic fouling affinity for water desalination. Desalination 2015, 368, 106-113. [CrossRef]

77. Ghaemi, N.; Madaeni, S.S.; Daraei, P.; Rajabi, H.; Zinadini, S.; Alizadeh, A.; Heydari, R.; Beygzadeh, M.; Ghouzivand, S. Polyethersulfone membrane enhanced with iron oxide nanoparticles for copper removal from water: Application of new functionalized Fe3O4 nanoparticles. Chem. Eng. J. 2015, 263. [CrossRef]

78. Zirehpour, A.; Rahimpour, A.; Arabi Shamsabadi, A.; Sharifian, M.G.; Soroush, M. Mitigation of Thin-Film Composite Membrane Biofouling via Immobilizing Nano-Sized Biocidal Reservoirs in the Membrane Active Layer. Environ. Sci. Technol. 2017, 51, 5511-5522. [CrossRef] [PubMed]

79. Shakeri, A.; Salehi, H.; Ghorbani, F.; Amini, M.; Naslhajian, H. Polyoxometalate based thin film nanocomposite forward osmosis membrane: Superhydrophilic, anti-fouling, and high water permeable. J. Colloid Interface Sci. 2019, 536, 328-338. [CrossRef] [PubMed]

80. Zhang, X.; Wang, Z.; Chen, M.; Ma, J.; Chen, S.; Wu, Z. Membrane biofouling control using polyvinylidene fluoride membrane blended with quaternary ammonium compound assembled on carbon material. J. Membr. Sci. 2017, 539, 229-237. [CrossRef]

81. Mooss, V.A.; Hamza, F.; Zinjarde, S.S.; Athawale, A.A. Polyurethane films modified with polyaniline-zinc oxide nanocomposites for biofouling mitigation. Chem. Eng. J. 2019, 359, 1400-1410. [CrossRef]

82. Carmalin Sophia, A.; Lima, E.C.; Allaudeen, N.; Rajan, S. Application of graphene based materials for adsorption of pharmaceutical traces from water and wastewater-A review. Desalin. Water Treat. 2016, 3994, 1-14. [CrossRef]

83. Chang, X.; Wang, Z.; Quan, S.; Xu, Y.; Jiang, Z.; Shao, L. Exploring the synergetic effects of graphene oxide (GO) and polyvinylpyrrodione (PVP) on poly (vinylylidenefluoride) (PVDF) ultrafiltration membrane performance. Appl. Surf. Sci. 2014, 316, 537-548. [CrossRef]

84. Castro-Muñoz, R.; Buera-Gonzalez, J.; de la Iglesia, O.; Galiano, F.; Fíla, V.; Malankowska, M.; Rubio, C.; Figoli, A.; Téllez, C.; Coronas, J. Towards the dehydration of ethanol using pervaporation cross-linked poly(vinyl alcohol)/graphene oxide membranes. J. Membr. Sci. 2019, 582, 423-434. [CrossRef]

85. Nair, R.R.; Wu, H.A.; Jayaram, P.N.; Grigorieva, I.V.; Geim, A.K. Unimpeded Permeation of Water Through Helium-Leak-Tight Graphene-Based Membranes. Science 2012, 335, 442-445. [CrossRef] [PubMed]

86. Shen, L.; Bian, X.; Lu, X.; Shi, L.; Liu, Z.; Chen, L.; Hou, Z.; Fan, K. Preparation and characterization of ZnO / polyethersulfone (PES) hybrid membranes. DES 2012, 293, 21-29. [CrossRef]

87. Zhao, S.; Yan, W.; Shi, M.; Wang, Z.; Wang, J. Improving permeability and antifouling performance of polyethersulfone ultra fi ltration membrane by incorporation of $\mathrm{ZnO}-\mathrm{DMF}$ dispersion containing nano-ZnO and polyvinylpyrrolidone. J. Membr. Sci. 2015, 478, 105-116. [CrossRef]

88. Balta, S.; Sotto, A.; Luis, P.; Benea, L.; Van der Bruggen, B.; Kim, J. A new outlook on membrane enhancement with nanoparticles: The alternative of ZnO. J. Membr. Sci. 2012, 389, 155-161. [CrossRef]

89. Ahn, S.; Cong, X.; Lebrilla, C.B.; Gronert, S. Zwitterion formation in gas-phase cyclodextrin complexes. J. Am. Soc. Mass Spectrom. 2005, 16, 166-175. [CrossRef]

90. Venault, A.; Huang, W.Y.; Hsiao, S.W.; Chinnathambi, A.; Alharbi, S.A.; Chen, H.; Zheng, J.; Chang, Y. Zwitterionic Modifications for Enhancing the Antifouling Properties of Poly(vinylidene fluoride) Membranes. Langmuir 2016, 32, 4113-4124. [CrossRef]

91. Bott, T.R. Potential physical methods for the control of biofouling in water systems. Chem. Eng. Res. Des. 2001, 79, 484-490. [CrossRef]

92. Van der Bruggen, B. Chemical modification of polyethersulfone nanofiltration membranes: A review. J. Appl. Polym. Sci. 2009, 114, 630-642. [CrossRef] 
93. Jiang, B.B.; Sun, X.F.; Wang, L.; Wang, S.Y.; Liu, R.D.; Wang, S.G. Polyethersulfone membranes modified with D-tyrosine for biofouling mitigation: Synergistic effect of surface hydrophility and anti-microbial properties. Chem. Eng. J. 2017, 311, 135-142. [CrossRef]

94. Hegab, H.M.; ElMekawy, A.; Barclay, T.G.; Michelmore, A.; Zou, L.; Saint, C.P.; Ginic-Markovic, M. Effective in-situ chemical surface modification of forward osmosis membranes with polydopamine-induced graphene oxide for biofouling mitigation. Desalination 2016, 385, 126-137. [CrossRef]

95. Wibisono, Y.; Yandi, W.; Golabi, M.; Nugraha, R.; Cornelissen, E.R.; Kemperman, A.J.B.; Ederth, T.; Nijmeijer, K. Hydrogel-coated feed spacers in two-phase flow cleaning in spiral wound membrane elements: Anovel platform for eco-friendly biofouling mitigation. Water Res. 2015, 71, 171-186. [CrossRef] [PubMed]

96. Jung, Y.; Alayande, A.B.; Chae, S.; Kim, I.S. Applications of nisin for biofouling mitigation of reverse osmosis membranes. Desalination 2018, 429, 52-59. [CrossRef]

97. Katalo, R.; Okuda, T.; Nghiem, L.D.; Fujioka, T. Moringa oleifera coagulation as pretreatment prior to microfiltration for membrane fouling mitigation. Environ. Sci. Water Res. Technol. 2018, 4, 1604-1611. [CrossRef]

98. Qasim, M.; Darwish, N.N.; Mhiyo, S.; Darwish, N.A.; Hilal, N. The use of ultrasound to mitigate membrane fouling in desalination and water treatment. Desalination 2018, 443, 143-164. [CrossRef]

99. Ma Wen Panecka, M.; Tufenkji, N.; Rahaman, M.S. Bacteriophage-based strategies for biofouling control in ultrafiltration: In situ biofouling mitigation, biocidal additives and biofilm cleanser. J. Colloid Interface Sci. 2018, 523, 254-265. [CrossRef]

100. Ali, J.; Wang, L.; Waseem, H.; Sharif, H.M.A.; Djellabi, R.; Zhang, C.; Pan, G. Bioelectrochemical recovery of silver from wastewater with sustainable power generation and its reuse for biofouling mitigation. J. Clean. Prod. 2019, 235, 1425-1437. [CrossRef]

101. Ergön-Can, T.; Köse-Mutlu, B.; Koyuncu, İ.; Lee, C.H. Biofouling control based on bacterial quorum quenching with a new application: Rotary microbial carrier frame. J. Membr. Sci. 2017, 525, 116-124. [CrossRef]

102. Al-Abri, M.; Al-Ghafri, B.; Bora, T.; Dobretsov, S.; Dutta, J.; Castelletto, S.; Rosa, L.; Boretti, A. Chlorination disadvantages and alternative routes for biofouling control in reverse osmosis desalination. Npj Clean Water 2019, 2. [CrossRef]

103. Klein, T.; Zihlmann, D.; Derlon, N.; Isaacson, C.; Szivak, I.; Weissbrodt, D.G.; Pronk, W. Biological control of biofilms on membranes by metazoans. Water Res. 2016, 88, 20-29. [CrossRef]

104. Armbruster, S.; Stockmeier, F.; Junker, M.; Schiller-Becerra, M.; Yüce, S.; Wessling, M. Short and spaced twisted tapes to mitigate fouling in tubular membranes. J. Membr. Sci. 2020, 595, 117426. [CrossRef]

(C) 2020 by the authors. Licensee MDPI, Basel, Switzerland. This article is an open access article distributed under the terms and conditions of the Creative Commons Attribution (CC BY) license (http://creativecommons.org/licenses/by/4.0/). 